\title{
Valuations and their importance for real estate investments
}

Book or Report Section

Accepted Version

Crosby, N., Hutchison, N., Lusht, K. and Yu, S. M. (2018)

Valuations and their importance for real estate investments. In:

MacGregor, B. D., Schulz, R. and Green, R. K. (eds.)

Routledge Companion to Real Estate Investment. Routledge, Abingdon. ISBN 9781138020788 Available at https://centaur.reading.ac.uk/83214/

It is advisable to refer to the publisher's version if you intend to cite from the work. See Guidance on citing.

Publisher: Routledge

All outputs in CentAUR are protected by Intellectual Property Rights law, including copyright law. Copyright and IPR is retained by the creators or other copyright holders. Terms and conditions for use of this material are defined in the End User Agreement.

\section{www.reading.ac.uk/centaur}

\section{CentAUR}

Central Archive at the University of Reading 
Reading's research outputs online 


\section{Chapter 8: Valuations and their importance for real estate investments}

\section{Neil Crosby}

University of Reading, England, $U K$

\section{Norman Hutchison,}

University of Aberdeen, Scotland, UK

\section{Kenneth Lusht}

Penn State University, USA

\section{Shi Ming Yu \\ National University of Singapore}

\section{Introduction}

This chapter considers the need for valuations and outlines the growth of the valuation profession over the last 150 years across the world. Background market information is provided on selected markets, and valuation standards are discussed and definitions provided. Valuation methodologies are then explained along with reporting requirements and the chapter concludes with an overview of market practice. Throughout, the terms 'valuation' and 'appraisal' are used interchangeably. For consistency, valuation will be used unless the term appraisal forms part of the official name of an organisation, standards or qualifications, which is particularly the case in the US and China.

In a single chapter, it is not possible to give an in-depth analysis of the real estate market in each country but Appendix A provides a brief description of the different legal and real estate market systems and covers, property rights, title, units of measurement and typical lease structures.

\section{Why we need valuations}


Valuations are required for a number of purposes including the buying and selling of property, development appraisal, monitoring the level of property performance, loan security, tax matters, company accounts and insurance reinstatement. The lack of a central trading market and the opaqueness of the market mean that investors in real estate are not able immediately to obtain a valuation of their asset. Instead, investors rely on independent valuers to provide this service. The purpose of the valuation and the type of property that is to be valued will determine the basis of the valuation and the techniques that should be employed. The basis of valuation, for example 'Market Value' or 'Market Rent', are discussed later in the chapter.

The main requirement of the major investors is for performance measurement and valuations provide the data for this to be carried out. Information on capital value, Market Rent and the components which have driven performance, such as yield shift and rental growth, provide the level of information needed to analyse the performance of real estate investments over different time periods.

\section{The Valuation Profession}

\section{The United States}

Though professional valuation associations in the US trace their beginnings to the late 1920s, the modern regulatory environment for real estate appraisers and valuations can be traced to the collapse of commercial property markets and the savings and loan industry (which had made a substantial percentage of construction loans) beginning in the late 1980s. Legislation and subsequent regulation beginning at that time established the Appraisal Foundation, and effectively mandated state licensing and certification of appraisers. The Appraisal Foundation has established minimum appraisal standards (through its Appraisal Standards Board), minimum qualifications for appraisers (through its Appraisal Qualifications Board), and more recently has begun issuing guidelines for valuation practice (through its Appraisal Practices Board). These standards are the basis for state regulations with respect to education and experience requirements for licensing and certification. Though the details of those requirements vary across the states, they must pass the test of 'adequacy' with respect to standards and qualification. Appraisers typically progress from 
an Appraisal Training Licence to either a Certified Residential Appraiser (certified to appraise residential properties) and/or a Certified General Appraiser (certified to appraise all properties). Each licensing/certification level carries with it increasing education and experience requirements. In addition, those licensed or certified must periodically complete state-mandated continuing education.

There are approximately 95,000 real estate appraisers in the US, which is about $10 \%$ fewer than in the mid-2000s. The declining number of appraisers can be traced to the collapse of housing markets beginning in 2006, and the demographics of the valuation profession. More than half of appraisers are currently in the 51-65 age group, and only about 12\% are under the age of 35 . As a result, various industry observers forecast increasing demand for appraisers in the foreseeable future.

The industry is fragmented, with about $50 \%$ of firms being single-owner operators, and the average number of employees per firm about 1.4. There are a few national and regional firms, but the market share of the top five of these is less than $15 \%$, with the largest having about $6 \%$.

The largest demand for valuation services comes from mortgage lenders. As part of the increasing regulation of the industry, valuation assignments for lending purposes must now be administered through third-party Appraisal Management Companies. The motivation for the mandate of AMCs is an attempt to separate the valuer from direct contact with the mortgage lender; contact which some believe may compromise the independence of the valuer.

In addition to required state licensing and certification, some valuers choose to differentiate themselves by membership of professional valuation associations. These associations require additional education and experience in order to qualify for professional designations. The Appraisal Institute is the most visible and arguably most prestigious of these associations. The two designations offered through the Appraisal Institute are the SRA (a residential designation), and the MAI (a general designation). Unpublished surveys undertaken by the Appraisal Institute suggest those holding the MAI designation can expect higher earnings, controlling for other variables. 


\section{The United Kingdom}

In the UK, the major professional institution for property valuers is the Royal Institution of Chartered Surveyors (RICS). It can trace its history back to 1792 but more formally to 1868 , albeit with a much wider remit than valuation (RICS, 2014a). The requirement for such an organisation was driven by rapid industrialisation: as infrastructure, housing and transport links grew, so did the need for more stringent checks and balances. The Royal Charter requires members to promote the usefulness of the profession for the public advantage in the UK and in other parts of the world. Over the years, it has taken over or merged with many of the other professional organisations representing valuers, for example, the Chartered Land Agents' Society and the Chartered Auctioneers' and Estate Agents' Institute in 1970 and, most recently, in 2000 with the Incorporated Society of Valuers and Auctioneers.

Given the size and coverage of the RICS, it is split into 17 professional groups of which the Valuation Professional Group is one. Professional groups focus on four main areas:

- Standards

- Professional Statements

- Market insights

- Regulation

The valuation professional group covers the following areas of practice.

- General valuation

- Compensation bases

- Assessment for compulsory acquisition

- Investment appraisal

- Performance measurement and analysis

- Decision taking

- Rating valuation and property taxation law and practice

- Property funding and financing

Therefore it is this group that has responsibility for developing and maintaining the RICS Valuation Professional Standards and all the other valuation-related professional guidance (codes of practice, guidance notes and information papers). 
The most common route to membership is by an accredited degree followed by two years' work experience culminating in an Assessment of Professional Competence (APC). There are three grades of membership, FRICS (Fellow), MRICS (Member) and AssocRICS (Associate), with a global membership of around 120,000 organised around professional groups covering the full remit of land, property and construction. The valuation profession in the UK is run under a selfregulation model, with the members internally monitored and inspected. Since 2011, as a further layer of quality assurance, all valuers who wish to undertake valuations based on the RICS Professional Standards (commonly referred to as the Red Book) must not only be a member of the RICS but are also required to be Registered Valuers with the Institution. It accredits individuals not firms. This is a monitoring programme for all members undertaking valuations in accordance with the mandatory RICS valuation standards.

\section{Asia - overview}

Given the size and complexities of Asia, only a few key countries are highlighted in this chapter. The countries chosen were selected based on their significance economically as well as their role in real estate developments and activities in the region and include Australia, China, Hong Kong, India, Japan, and Singapore.

These six leading countries of Asia demonstrate a diverse set of regulatory environments and the current structure and state of the valuation industry. Nevertheless, two distinct groupings can be identified. First, the countries which are part of the British Commonwealth: Australia, Hong Kong, India, and Singapore. These countries have laws and practices which can be traced to their colonial periods and the present regulatory environments and valuation practices are still very similar to those of the United Kingdom. The RICS has been established in these countries and continues to play a significant role in the valuation profession. The second grouping includes Japan and China, countries with distinctive regulatory environments depending largely on their historical, political and economic developments over the years. Japan, as the third largest economy in the world (based on GDP), is very well-established both in terms of the regulatory framework as well as the valuation industry. China, the world's potentially largest economy, has witnessed the 
greatest pace of development, especially in the real estate sector and the attendant services including valuation. The structure of the profession in each country is considered in turn.

\section{$\underline{\text { Australasia }}$}

The Australian Property Institute (API) can trace its history back to the formation of the Commonwealth Institute of Valuers in 1926, and is the national professional body for property professionals with about 8,500 members some of whom have certified practising valuer status (CPV). The criteria for membership include possessing an approved undergraduate degree; a minimum of two years' relevant professional experience; demonstrating a satisfactory record of continuing professional development; approval by an interview panel and continuing compliance with the API's code of ethics and rules of conduct The Property Institute of New Zealand was formerly the New Zealand Institute of Valuers, established in 1942. The current organization was formed in the year 2000 and incorporated the membership of the New Zealand Institute of Valuers (NZIV), the Institute of Plant \& Machinery Valuers (IPMV), and the Property \& Land Economy Institute of New Zealand (PLEINZ) and has about 2,500 members. In 2017, the two Institutes represent the interests of more than 11,000 property specialists throughout Australia and New Zealand. They produce a combined valuation standard for the two countries

In 2017, the API formed a strategic alliance with RICS. This alliance has three strands. First, the two organisations have aligned their registration schemes. API members will adopt the RICS global assurance regime of valuer registration. Second, the alliance will lead to a common valuation standard with API adopting the global Red Book with both parties developing aligned national standards for Australasia, presumably with PINZ. Finally, the API aims to align its qualification pathways to that of RICS. Once completed, both API members and RICS professionals will be mutually recognised by both organisations in Australia and there will be one process and membership (either API or RICS) rather than the two different processes.

\section{$\underline{\text { China }}$}


The main professional valuation body in China is the China Appraisal Society (CAS) which was established in 1993 under the purview of the Ministry of Finance. As of 2005, it had approximately 29,000 members. One of the aims of the CAS is to assist members in improving their professional skills and to advance the credibility of the profession. Other professional bodies include the China Institute of Real Estate Appraisers and Agents (CIREA) and the China Real Estate Valuation Association (CREVA).

In order to be a qualified real estate appraiser in China, a candidate must first pass the real estate appraiser licensing examination, which is conducted annually, to obtain a Real Estate Appraiser Qualification Certificate, whereupon a Real Estate Practicing Appraiser Qualification Certificate (REPAC) will be issued by the government. A qualified appraiser holding a REPAC must apply to the government to be registered within three months of issuance of the REPAC. Registration is valid for a term of three years.

For land valuations, a similar annual licensing examination is conducted. A candidate who passes the examination will be issued a Land Appraiser Qualification Certificate (LAQC). The holder of a LAQC must then pass a work experience assessment conducted by the Land Appraiser Association of China in order to become a practicing appraiser.

\section{Hong Kong}

Members of the Hong Kong Institute of Surveyors (HKIS) and Royal Institution of Chartered Surveyors (RICS) are qualified to value real estate in Hong Kong. HKIS is Hong Kong's professional surveying institute. It is the only professional organisation representing surveying practitioners in Hong Kong. HRIS members numbered 9,091 ${ }^{1}$ in 2014.

$\underline{\text { India }}$

The main professional valuation body in India is the Practising Valuers Association of India (PVAI). It was incorporated in 1999 and is a self-funded and independent organisation. However, there is no centralised oversight of the valuation profession in India. Members of the Institution 
of Valuers, the first national professional valuation society in India, established in 1968, may practice valuation as an approved valuer. Their backgrounds are mainly in architecture and civil engineering. The Institution of Surveyors also conducts Valuation Surveying examinations which are recognised by the Government of India. ${ }^{2}$ Other recognised bodies include the Institution for Government Approved Valuers, the Royal Institution of Chartered Surveyors, India Chapter, and the Valuation Institute, USA.

$\underline{\text { Japan }}$

Valuation practitioners in Japan are regulated and licensed by the Japanese Association of Real Estate Valuation (JAREA), established in 1965, and which falls under the purview of the Ministry of Land, Infrastructure and Transportation (MLIT). To be a certified valuer, a person must pass the national examination to be a Licensed Real Property Appraiser and undergo technical training.

\section{$\underline{\text { Singapore }}$}

Singapore has a relatively small valuation profession that is regulated by the Inland Revenue Authority of Singapore. Licensed valuers are required to possess a relevant undergraduate degree such as a bachelor's degree in real estate from the National University of Singapore or a similar degree from an accredited overseas institution, or equivalent professional qualifications certified by the RICS, and relevant practical professional valuation experience.

The Singapore Institute of Surveyors and Valuers (SISV), established in 1982, is the only professional body that represents land surveyors, quantity surveyors and valuers nationwide. The aims of the SISV are to advance and facilitate the acquisition of professional knowledge in the areas of land surveying, quantity surveying and valuation and general practice surveying, to promote the general interests of the profession, to maintain and improve its usefulness for the benefit of the public, and to regulate and improve the standards and conduct of the profession. ${ }^{3}$ With businesses in Singapore securing more overseas development opportunities, demand for international valuation consultancy services by Singapore-based clients has been rising. As a result, international valuation standards, such as those promulgated by RICS, have gained traction 
with Singapore consultancy firms. For example, in 2004, Colliers International, one of the leading property consultancies, announced that it would embark on a scheme to register all its valuers for RICS Valuer Registration across the region with the aim of raising standards and pursuing service excellence.

\section{Valuation standards}

\section{A brief history}

Over the last 40 years since the 1970s, there has been significant progress in first producing and then developing consistent real estate valuation standards across the world. At the beginning of the 1970s, there was no formal framework for the production of guidance and standards, although there were already well-established organisations of professional valuers set up to provide, among other things, education and guidance to their fellow valuers.

It was, arguably, the major property crash in the UK in the early 1970s that precipitated the drive to formal valuation standards. Before that period, guidance had been in the form of the production of rules for statutory valuations, and practitioner and academic textbook suggestions regarding methods of valuation (such as, in the UK, Modern Methods of Valuation, which had its first edition published in 1943 (Lawrence and May, 1943); and, in the US, Valuation of Real Estate, first published in 1951 by the Appraisal Institute, (AI, 2014)). An earlier UK text, Curtis on the Valuation of Land and Houses, had seven editions ranging from before 1900 to 1933 (for example, Davies, 1908, 3e). In response to criticism from users of valuations and observers of property markets following the 1970s property market crash, the RICS published the first set of national UK standards in 1976 followed by new editions in 1981 and 1990. At the time of writing, the latest edition is 2017 and this edition incorporates the International Valuation Standards of 2017. The official title is currently RICS Valuation-Global Standards but it is universally known as the RICS Red Book (RICS, 2017). The RICS now publish their Global Red Book separately from their national UK supplement; at the time of writing the national UK Red Book was last revised in 2015 but a revised version is due in 2018. 
The US Uniform Standards of Professional Appraisal Practice (USPAP) was also developed in the wake of a savings and loan crisis. It can be traced to the work of an ad hoc group established in 1987 by nine Canadian and US appraisal organisations. In 1989, USPAP was formally established by The Appraisal Foundation (TAF), a non-profit regulatory organisation. TAF has the responsibility of establishing, improving and promoting minimum uniform appraisal standards, appraiser qualifications, and guidelines with respect to appraisal practice. The USPAP are revised every two years.

The origins of International Valuation Standards (IVS) lie in the International Assets Valuation Standards Committee (TIAVSC), which was formed in 1981 in Melbourne, Australia following initial discussion between, mainly, US and UK valuer organisations. Its objective was the development of consistent standards across national borders. Commencing with co-operation among 20 organisations, it has around 90 organisations in membership from 57 countries (www.ivsc.org). It first produced standards in 1985 and at the time of writing the latest edition is 2017 (IVSC, 2017).

Alongside the development of national and international standards, there also have been some attempts to set up intermediary standards at a regional level, the most obvious case being within the European Union. At the time of writing, the current edition is the eighth set of European Valuation Standards, produced by the European Group of Valuers' Associations (TEGOVA) and published in 2016. The first edition was published in the early 1980s. In the past, there has been some tension between the objectives of the International and European standard setting bodies but this has now receded as TEGOVA has adopted most of the principles of IVS and concentrates on EU issues, as well as promoting the development of national standards within EU countries. As indicated previously, another example is the combined Australia and New Zealand standard.

\section{The content of valuation standards}

The 2017 IVS contains the IVS Framework, the IVS General Standards and the IVS Asset Standards. The current edition was approved by the IVSC Standards Board for implementation 
on 1 July 2017. Current policy is to review the standards every 2 years. IVSC also produces freestanding Technical Information Papers (TIPs) available as separate booklets.

The IVS Framework identifies generally accepted principles and concepts including issues surrounding competency, objectivity, judgment and departures and does not include any procedural requirements. IVS General Standards sets out the requirements for the conduct of all valuation assignments such as engagement, bases, methods and reporting and is designed to be applicable to all types of assets and for any valuation purpose. The IVS Asset Standards has both requirements and commentaries, including illustrations of how the principles in the General Standards are generally applied to different types of asset such as real property, intangible property and business property.(.

Given that IVS are sponsored by a significant number of countries, it is not surprising that, in the most part, national (and regional) valuation standards such as the RICS Red Book or USPAP tend to repeat the principles set out in the IVS, but retain a national standard to cope with national variations. For example, the RICS Red Book (RICS, 2014b) uses the IVS Standards in its Global Practice Statements; but then includes four mandatory UK Practice Statements with 14 supporting appendices and an additional seven UK Guidance Notes for the national market. It also encourages its international members to develop local statements and guidance notes for individual countries based around the global section of the Red Book.

Arguably, the most controversial issue is how far standards should go in identifying valuation methods for different purposes or situations. Over the years, while valuation standards have been developing, opinion within the valuation standards setting bodies, internationally, regionally and nationally, has tended to sway between being more or less prescriptive on method. Some of this relates to whether the regulation of the valuation industry in a particular country is by government or self-regulation by the industry. This has resulted in a variety of additional information papers and/or guidance notes that illustrate and illuminate the application of the standards and, in some cases, methods. 
Valuation standards predominantly try and regulate and control the process by which valuations are produced, especially those that can impact on third party decisions, such as information within financial statements concerning a company or fund or the behaviour of lenders and borrowers. To that end, valuation standards address issues of objectivity, including ethical standards and conflicts of interest and competence (that is, the correct knowledge and skills for any particular task). As far as the actual process is concerned, the IVS address the selection of the valuer, the format of instructions, concepts and definitions of value (often related to purpose of the valuation) and reporting of valuations (including the content of reports but also the process around reporting of draft valuations as well as final reports). These issues, as well as methods, are addressed in the following sections of this chapter.

Other codes of practice and guidance which impact on property valuations can be found - for example, in the UK, the RICS has produced a range of papers outside the remit of its valuation standards board. Over 30 are listed in the Red Book, around half of which have valuation in the title. Other examples of guidance outside of the standards is the current move (2017) in Australia to produce Technical Information Papers to support their standards. Whether additional guidance is included within or without the standards it is important to note that it is quite usual across many valuation standards to have some parts mandatory and some guidance.

As an example of standard setting in another jurisdiction, the HKIS stipulates mandatory valuation standards for real estate valuations in Hong Kong. The standards cover the criteria for qualification as a professional valuer, the matters which a professional valuer should consider in their terms of engagement, the basis of a professional valuation, assumptions and key considerations that should be addressed, minimum standard forms for a valuation report and required disclosures. IVSC standards are also adopted by the HKIS as supplementary to its own standards.

Another recent global initiative which affects valuation is the attempt to produce consistent global measuring practices through an internationally agreed code of measuring practice (The International Property Measurement Standard - http://ipmsc.org/). This will ensure that units of value per unit of space are more comparable across countries. However, inconsistencies remain, for example, different terms of rent contracts mean that property incomes expressed as yields are 
not comparable across countries with major differences between the percentages of gross income retained by owners in different countries ${ }^{4}$.

Specific valuation issues, such as bases of valuation and conflicts of interest, and their implications, have been and will be discussed in more detail at different points in this handbook, both in this and other chapters.

\section{Definitions}

International Valuation Standards (IVSC, 2017) identify the following bases of valuation.

- Market Value is the estimated amount for which an asset or liability should exchange on the valuation date between a willing buyer and a willing seller in an arm's length transaction, after proper marketing and where the parties had each acted knowledgeably, prudently and without compulsion (Section 30)

- Market Rent is the estimated amount for which an interest in real property should be leased on the valuation date between a willing lessor and a willing lessee on appropriate lease terms in an arm's length transaction, after proper marketing and where the parties had each acted knowledgeably, prudently and without compulsion.

- Equitable Value is the estimated price for the transfer of an asset or liability between identified knowledgeable and willing parties that reflects the respective interests of those parties. 50.2. Equitable Value requires the assessment of the price that is fair between two specific, identified parties considering the respective advantages or disadvantages that each will gain from the transaction. In contrast, Market Value requires any advantages or disadvantages that would not be available to, or incurred by, market participants generally to be disregarded.

- Investment Value/worth is the value of an asset to the owner or a prospective owner for individual investment or operational objectives (Section 60).

- Synergistic Value is the result of a combination of two or more assets or interests where the combined value is more than the sum of the separate values. If the synergies are only available to one specific buyer then Synergistic Value will differ from Market Value, as the Synergistic Value 
will reflect particular attributes of an asset that are only of value to a specific purchaser. The added value above the aggregate of the respective interests is often referred to as "marriage value."

- Liquidation Value is the amount that would be realised when an asset or group of assets are sold on a piecemeal basis. Liquidation Value should take into account the costs of getting the assets into saleable condition as well as those of the disposal activity. Liquidation Value can be determined under two different premises of value: (a) an orderly transaction with a typical marketing period, or a forced transaction with a shortened marketing period.

IVS (2017) also identifies a number of other bases of value which it does not define, the majority of these are tied to specific regulatory or legal issues and a number are country specific. The most important of these is Fair Value used within International Financial Reporting Standards. IFRS 13 defines Fair Value as the price that would be received to sell an asset or paid to transfer a liability in an orderly transaction between market participants at the measurement date. For financial reporting purposes, over 130 countries require or permit the use of the International Accounting Standards. The Financial Accounting Standards Board in the United States uses the same definition of Fair Value. (IVSC, 2017)

\section{Exchange value concepts}

The Market Value basis dominates property valuation. It is an exchange price concept and is supposed to identify the price at which a property interest actually exchanges in a free market with all participants acting knowledgeably and without any compulsion. IVSC (2017)

distinguishes it from fair value. As indicated above, International Financial Reporting Standards define Fair Value as the 'price that would be received to sell an asset or paid to transfer a liability in an orderly transaction between market participants at the measurement date'. The RICS Global standards suggest that "references within [Accounting Standards (IFRS 13)] to market participants and a sale make it clear that for most practical purposes the concept offair value is consistent with that of market value, and so there would ordinarily be no difference between them in terms of the valuation figure reported." RICS, 2017, VPS4, Para 7.3) 
There are issues with Market Value as it tries to define a single point estimate of price of an asset that takes time to transact and has no centralised market place of identical assets. There is, therefore, variation around any estimate and this variation has been the subject of much research and comment (see, for example, MSCI, 2017) ). These issues are discussed in the chapter on property valuation-based indices. The timing of the date of valuation is at the end of a normal marketing period. So the valuer has to assume that the property has been placed on the market some time previously, to allow a proper marketing period before the date of valuation, but that the prevailing market conditions have been as they are at the date of valuation. Market Value is, therefore, not the same price as would be expected if the property was put on the market at the valuation date and marketed properly from that date. The price would then be agreed at some point in the future in a market that might have changed.

A Liquidation value is a new basis of value in IVSC (2017). It is linked to what has formally been called a forced sale value which IVS does not recognise as a separate basis. The distinctions are set out in IVS $(2017$, p25). A "forced" sale has often been characterised as a market value under a restricted marketing period. The use of special assumptions can be adopted to enable clients to specify valuations which answer particular needs. A restricted marketing period could be a special assumption as would be an assumption that a particular permission was in place when it is not, or a lease in place when it is not (or vice versa) or even that the property is not quite the same physically as it actually is (age at the end of a loan period rather than at the beginning for example). IVS comments that All assumptions and special assumptions must be reasonable under the circumstances, be supported by evidence, and be relevant having regard to the purpose for which the valuation is required (IVSC, 2017, p28)

Market Value assumes highest and best use (assuming both permissible and viable development/change of use) and a market consisting of 'numerous' buyers and sellers. Market Value does not acknowledge any special advantages to an individual. Equitable Value andSynergistic Value do acknowledge these issues. Equitable Value accepts that one individual may get/have a special advantage over and above all others from ownership of a particular asset and Synergistic Value that advantage that may come from combining or restructuring interests. 
Finally, rental values are just as important to property investors as capital values and IVS defines rental value as 'Market Rent'. Market Rent is defined as 'the estimated amount for which an interest in real property should be leased on the valuation date between a willing lessor and a willing lessee on appropriate lease terms in an arm's length transaction, after proper marketing and where the parties had each acted knowledgeably, prudently and without compulsion'. It is virtually the same definition as Market Value but has the added complication of rental value being affected by the terms of the lease contract. The definition identifies only 'appropriate lease terms' so each rental value assessment requires the valuer to report the assumed lease terms. Incentives to secure lettings such as rent free periods, stepped rents, landlord capital contributions to tenant fit out expenditure and other non-specific contributions all lead to some major adjustments to headline rents paid from the effective rental value that would have been paid for the premises from day one of the lease with no incentive package. In addition to any difficulties this creates in analysing comparable lettings, it distorts valuation-based rental value indices used to measure occupational markets, as the detail of all the terms of the deal may not be known or analysed consistently by all the market participants to get the effective rent. This issue is discussed further in the Chapter 11 on valuation-based indices.

\section{Investment Value}

The other main basis of value identified in the IVS is Investment Value. It is a value in use concept tied to a particular purchaser or owner and is not an identification of the expected exchange price of the asset at the date of valuation. It had its genesis in the 1990s in a period where there was evidence of systematic mis-pricing of property assets in the UK market after the second major property crash in that country, not additional value created by the individual circumstances of particular investors. Assessments of Market Value were primarily undertaken using comparable capitalisation rate techniques but major investors had invested heavily in research, enabling them to model property markets into the future using cash flow techniques. This modelling often identifies individual assets or locations or segments that are deemed to be mis-priced by the market. Early definitions of Investment Value introduced into the Red Book were called 'Calculations of Worth' by the RICS to distinguish them from a valuation. The definition contained reference to both individuals and groups of investors, acknowledging that an asset can have a different value 
than Market Value or price to a wider investing community, rather than just to an individual. The current IVS definition is, therefore, a major step backwards as the reference to groups of investors has been removed (IVS, 2017).

\section{Mortgage Lending Value}

There is one other concept and definition of value that is not included in IVS but cannot be ignored, especially in the aftermath of the global financial crisis. Sustainable value, in the sense that it can be sustained through time, is the conceptual basis for Mortgage Lending Value used by some Mainland European banks as a risk management tool for their commercial loan books. It is part of the Basel accords, along with Market Value, and is used in the determination of bank capital ratios. It is used in "covered bond" markets and within the German Pfandbrief bank loans for over a hundred years. The definition set out in the European Valuation Standards is:

'The value of the property as determined by a prudent assessment of the future marketability of the property taking into account long-term sustainable aspects of the property, the normal and local market conditions, the current use and alternative appropriate uses of the property. Speculative elements shall not be taken into account in the assessment of the Mortgage Lending Value.' (EVS, 2016)

EVS (2016, EVGN2) suggested that the 'intended purpose of Mortgage Lending Value is to provide a long-term, sustainable value as a stable basis for judging the suitability of a property as a security for a mortgage which will continue through potential market fluctuations.'

EVS (2016) provides further guidance which includes that the underlying time perspective goes beyond the short-term market and covers a long-term period. Longer term sustainable aspects include the quality of the location, construction and layout, that the income stream of the property should be no more than the 'sustainable' net rental income of that type of property. EVS suggests that this means "assessing the sustainable yield on the basis of a judgment of past and current market situation as well as future market trends and not taking any uncertain elements into account, e.g. possible future income growth”. (EVS, 2016, EVGN2) 
Some jurisdictions stipulate that a Mortgage Lending Valuation must be less than a Market Valuation. This suggests that it is not a long-term sustainable trend value that could, depending on cyclical movements in prices, be above MV in a recessionary market and below in a boom market. It suggests that it should be assessed to be no higher than any possible Market Value in a future or current trough in these jurisdictions (within the Pfandbrief Act regulations for example).

Not surprisingly, this approach has come under criticism, not for the objective of trying to introduce counter-cyclical constraints on bank lending through the valuation process, but for the lack of a conceptual and objective base to the valuations themselves (Crosby, French and Oughton, 2000; Crosby and Hughes, 2012). First, valuation has to have a valuation date and cannot provide a longer term value, but it could identify a future Market Value. However, forecasting is specifically excluded from the valuation. Second, the approach set out in texts and guidance (for example, Ruchardt, 2003) relies on rules rather than objective inputs. However, application does give one desired effect - a stable valuation that does not follow the cyclical movements of the market cycle. Nonetheless, the application of Investment Value using cash flow based on market data modelling gives exactly the same result in a more defensible manner, identifying under- as well as over-priced markets which MLV fails to do, and is a recognised basis of value with an established body of technique and analysis (Crosby and Hughes, 2012), especially in larger more mature markets with better data sources. The search for a better basis of valuation than using Market Value alone for lending is currently a major objective of stakeholders within property valuation and real estate finance.

\section{Valuer selection and instruction}

The genesis of valuation standards was industry concerns about the objectivity and accuracy of valuations in the wake of property market crashes. This was particularly apparent in valuations in the bank lending sector but also in the performance measurement and financial accounting roles. There are different issues for valuations which are performed regularly (performance measurement) against those that are one-off by nature (bank lending) but some of the major threats to objectivity come from a poor valuer selection process. In particular, client and other stakeholder 
influence on the outcome can be accomplished by having the 'right' valuer in place at the outset. Valuation standards have increasingly included statements on conflicts of interest, valuer selection and instructions. The IVSC has a separate paper on ethics (IVSC, 2011).

Valuation Professional Organisations that are members of the IVSC are required to have rules on ethical conduct by their members. A Valuation Professional Organisation may adopt the IVSC Code or maintain its own rules, providing such rules reflect the five Fundamental Principles of the IVSC Code. These principles are:

- Integrity: to be straightforward and honest in professional and business relationships.

- Objectivity: not to allow conflict of interest, or undue influence or bias to override professional or business judgement.

- Competence: to maintain the professional knowledge and skill required to ensure that a client or employer receives a service that is based on current developments in practice, legislation, and valuation techniques.

- Confidentiality: to respect the confidentiality of information acquired as a result of professional and business relationships and not to disclose such information to third parties without proper and specific authority (unless there is a legal or professional right or duty to disclose), nor to use information for the personal advantage of the professional valuer or third parties.

- Professional behaviour: to act diligently and to produce work in a timely manner in accordance with applicable legal requirements, technical and professional standards. To always act in the public interest and to avoid any action that discredits the profession.

IVSC (2011) sets out some of the potential threats to valuer objectivity and a number of them relate to client and other stakeholder influence and moral hazards for the valuer. There is a now a wealth of behavioural economics research aimed at client influence on valuations, including valuer selection processes, mainly from the US and UK but also from Asia Pacific and Africa. For the latest literature review, see Crosby, Lizieri and McAllister (2010) and, for an earlier review of this field, Diaz (2002) for the RICS Foundation. 


\section{Valuation methodologies: the users' perspective}

Valuations add value to the investment decision-making process by providing a third-party, unbiased, and (hopefully) informed estimate of what the property would be likely to sell for in the open market. The topic in this section is how those value estimates are developed. The underlying concepts and application details of the main valuation methodologies are discussed, including the implications for investment decision making of their relative strengths and limitations. We begin with an overall perspective on what valuation estimates are intended to be, and what they are not.

\section{Market Value estimates: some caveats}

A Market Value estimate is the valuer's opinion of the most probable selling price of the property. It is not the valuer's opinion of what the property may actually be worth. In other words, a valuation is an opinion of what will happen, not what should happen. This is a critical distinction, particularly during periods of market disequilibrium, when 'true' value and price may be significantly different. As a user of valuation estimates, it means that your valuation fee is not buying an opinion about whether a property is under or over- priced. It is buying only an opinion about what the price will be, not the wisdom of that price. A judgement about the relationship between prices and values can of course be obtained, but that must come from an individual in a non-valuation (consultant) role. The fact that some individuals' practices include both valuation and consulting makes it important to understand the difference.

Market Values and Investment Values often differ. Suppose we ask, say, ten investors what they would be willing to pay for a particular property. It is likely that we would get ten different answers. Each would reflect the property's Investment Value to a specific investor. Those Investment Values could differ for many reasons, for example, differences in risk tolerance, portfolio composition, tax status, or simply because of different expectations with respect to future cash flows. It is not clear where, in any distribution of Investment Values for an individual asset, the Market Value lies. It might be the mid-point but is more likely to be near to the top of the distribution given that Market Value is likely to be closer to the best price rather than the average price. If an Investment Value exceeds an asking price that reflects the appraised value, it may 
represent a positive net present value opportunity. Conversely, if the Investment Value falls below an asking price some negotiation would be necessary to make it an acceptable investment.

Valuation estimates are opinions, not facts. The methodologies that valuers use are models of the price determining process. Like all models, they are intended to simplify something exceedingly complex (price determination in real estate markets) into something more manageable. Paraphrasing statistician George Box, this means while all models are to some extent incorrect or incomplete, some (like valuation methodologies) are useful. These useful, though imperfect, models make estimates of prices that have yet to occur in markets that are themselves imperfect. With this understanding, you arrive at the important conclusion that valuation opinions are just that - unbiased and informed, but without the benefit of crystal balls.

\section{Valuation methodologies: overview}

The valuation opinions are developed using one or more of three basic methodologies, or approaches. They are 1) sales comparison, 2) cost, and 3) income. It is unusual for a valuation to include all three approaches. The kind of property, the available data, and perhaps regulatory or client requirements determine which approach(es) will be used in a particular situation. When two or more approaches are included, each will produce an estimate of value. Because valuers are modelling imperfect markets using imperfect models and often with imperfect data, only by extreme coincidence will the value estimates from different methodologies produce the same value estimate. Thus, the valuer's final 'number' will reflect the valuer's opinion as to which of the value estimates is most credible in that circumstance. Often this will be a weighted average (including the possibility of a zero weight for some estimates) of the individual value estimates produced by the approaches used.

\section{The Sales Comparison Approach}

Suppose someone were asked to provide a valuation of the current Market Value of a share of stock in a certain company. That would be an easy assignment, as a call to a broker or a glance at a ticker tape would provide the answer, which would be the price at which the last share sold. 
Though we may not think of it this way, estimating the share's value in this way is rooted in two fundamental assumptions. The first is that past selling prices are a reliable estimator of current price, and second, that the next share will sell for the same (or a very similar price) to the previous share. And we would be quite confident in the value estimate because the next share of that stock that sells will be identical to the previous share (on which you based your value estimate) and because in most cases the last sale occurred very recently.

The sales comparison approach to estimating a value in real property markets is based on the same kinds of assumptions, that is, market prices are a reliable (though imperfect) indicator of value, and that identical properties should sell for identical prices, especially when the transactions occur within a short period of time. Therefore, the starting point in the sales comparison approach is the same as it is when 'valuing' a share of stock, that is, the selling prices of comparable properties. After this starting point, however, the application of the approach begins to differ for two reasons. First, unlike our homogenous shares of stock, no two properties are identical and, second, unlike shares of stock, they tend to sell infrequently. So we need to modify our underlying assumption to something like: 'comparable (similar) properties will sell for comparable (similar) prices'. For property valuation, then, the sales comparison approach is about getting from the observed prices of comparable (similar) properties to an estimated value of the subject property.

For single family houses, this is done by adjusting the prices of the comparable properties for differences between them and the subject. These adjustments will reflect the familiar list of those things that impact values; things like location, size, age, various amenities and, perhaps, externalities.

The valuation of investment properties also begins with the selling prices of comparables but, because commercial properties tend to be more heterogeneous than houses, finding comparable properties sufficiently similar to the subject property is often difficult. This is especially so for differences in size. As a result, while the basic 'unit of comparison' for houses is the whole property, for commercial properties it is common practice to work with a smaller, more homogenous unit, such as the price per square foot. Adjustment for quantum may need to be made to the price per square foot/metre, if units are particularly large or particularly small and thus direct 
comparison is not possible. The unit of comparison used for a particular valuation will reflect how that property type is typically sold or leased in the market place. For an office building, the price of the comparable may be divided into the price per square foot/metre. For an apartment, common units of comparison are price per square foot/metre or per individual apartment. For a theatre, perhaps price per seat. In any event, this kind of approach allows value to be estimated on a more comparable basis. For example, if three sales of comparable retail properties indicate a price of $£ 50$ per square foot, that number would be multiplied by the number of square feet in the subject property to arrive at one indication of value. Because valuers are always looking for as many indications of value as possible, it is common for value to be estimated in this way for more than one unit of comparison. For example, an office building might be valued using both price per gross square foot and price per rentable square foot.

Not surprisingly, some units of comparison for investment properties are income based. In a sense, these units are bottom line relationships between expected income and value. Suppose an industrial property sold for $£ 10,000,000$, and it had expected annual gross income of $£ 500,000$. That relationship can be expressed by saying the property sold at a multiple of 20 times gross income (a Years' Purchase, or YP, of 20 in valuers' language), or that the initial yield or cap rate would be 5\%. If two other comparable sales produced gross income multiples of, say 18 and 22, the valuer would probably multiply the subject property's gross income by about 20 to arrive at the indication of value using that unit of comparison. All of this may sound familiar - it is exactly analogous to the frequent reporting of price to earnings ratios for securities, for example, that Company 'A' is selling at a price/earnings multiple of, say, 15.

Because for most valuations more than one unit of comparison is used, the valuer's final task within the sales comparison approach is to use his or her professional judgment to determine which of those units have produced the most credible estimate.

Strengths and limitations of the sales comparison approach 
The main strength of the sales comparison approach is that it is firmly anchored in observed market prices, which are direct and relatively objective evidences of value. For that reason, valuers tend to rely heavily on the estimates produced by sales comparison.

A limitation of the sales comparison approach is that its application is often compromised by a lack of sufficient comparable sales. This becomes increasingly likely as properties become larger and more heterogeneous, for example, when valuing regional shopping centers or unique office properties. In those situations, valuers commonly rely on the income approach (discussed below) as the primary evidence of value.

Another potential weakness of the sales comparison approach is that because it relies on past prices as the starting point, it is somewhat 'rear-view mirror' oriented. While an adjustment can be made to reflect changing market conditions between the date of sale of the comparable and the date of the valuation, studies have consistently observed this adjustment tends to be inadequate. The result is 'valuation lag', meaning values tend to fall below subsequent selling prices when markets are moving sharply upward, and vice versa.

For institutional investors, another potential problem is appraisal smoothing, discussed in more detail in Chapters 11 and 12 (Edelstein \& Quan, 2006; Geltner et. al., 2003). Smoothing sometimes occurs when properties in a portfolio are valued frequently for fiduciary and regulatory reasons, and the valuer is the same from valuation to valuation. The result may be value 'anchoring', where the estimate from one period tends to influence the estimate in the subsequent period. The result is a smoothing of value estimates, carrying with it the problem that those estimates are not picking up larger price changes occurring in the market.

\section{The Cost Approach}

The use of the cost approach to estimate the most probable selling price is rooted in the idea that the Market Value of a property should be the same as what it would cost to produce an identical property. Following that logic, the cost approach looks like this: 
Market Value $=$ Replacement (or reproduction) cost of the subject property's improvements as if new, minus accrued depreciation on the improvements, plus land value.

The cost model tells us that the valuer first estimates the value of the improvements as if they were to be built as of the date of the valuation. Unless the property is newly built, however, this 'cost new' will overstate the value of the improvements, as they will have lost some of their value over time. Thus, to get to the value of the improvements, depreciation must be subtracted from the cost as if new. Finally, the value of the underlying land is added to arrive at the estimate of property value.

It is helpful to think of the cost approach as a special case of sales comparison. Imagine two properties sitting side by side. They are identical as far as size, floor plan, building materials and other improvements to the site. However, one of the buildings is 10 years old, while the other is brand new. Suppose the 10 year old property is the subject property, and the identical (except new) property next door has recently sold. Using the identical property as a comparable in the sales comparison approach would require only a single adjustment — for the impact of 10 years of age (depreciation) - to arrive at an estimate of the value of the subject. This is exactly what happens when using the cost approach, where the cost to 'duplicate' a 'new' subject is first estimated, and then any value effects associated with the difference in age between the new subject and the actual subject is subtracted. Conceptually then, the cost approach is similar to the sales comparison approach, with all the variables held constant except for the effects of depreciation. That is, the subject is compared to a 'new' duplicate of itself.

There is strong intuitive appeal to the cost approach. On the demand side, potential buyers of a property have the alternative of purchasing an equivalent site and constructing equivalent improvements. Thus, it can be argued a buyer will pay no more for an existing property than it would cost to reproduce the property. Cost also disciplines price on the supply side. While sellers would like to get the highest price possible, in competitive markets, the cost to produce - defined to include a normal profit and to reflect the costs and risks associated with the development process - will effectively limit prices. That said, in some countries, such as the UK, land supply is 
restricted and those seeking alternative sites may well find a scarcity of supply, thus forcing up prices.

Strengths and limitations of the cost approach

Despite the intuitive appeal of the cost approach, it has serious limitations that often relegate it to a secondary role in value estimation. The main problem with using cost as a proxy for Market Value is that cost equals Market Value only when markets are in equilibrium. Unfortunately for the cost approach, in real estate markets, equilibrium tends to be elusive. Typically, there is an over or under supply of certain property types, meaning prices will fall below or above the cost to reproduce, which may be affected by local scarcity of land affecting the land price and cost inflation or deflation in the building cost component. While solutions to this difficulty are available, they involve adjusting the cost estimate to reflect any such disequilibrium. However, this process effectively transforms the cost approach into the sales comparison approach, making it somewhat redundant with respect to the value estimate.

A second limitation of the cost approach is that, as described above, it requires estimates of both physical depreciation as well as any functional obsolescence, and such estimates can be very difficult and imprecise, particularly when the subject's improvements are relatively old. Therefore, in practice, the cost approach tends to work better for newer rather than older properties.

Despite these conceptual and mechanical limitations, the cost approach is quite useful in certain situations. For investors and developers, the cost approach is valuable for analysing potential new development. Simply, when the Market Value at completion is expected to exceed the cost to produce, development is justified. When the reverse is true, development should not occur. Finally, a cost estimate may be mandated for some valuations, such as when estimating value for property insurance purposes.

\section{The Income Approach}


The rationale of the income approach is straightforward: the value of an income property, like the value of any investment, is a function of the income it is expected to produce, and the certainty of receiving the expected income. There are a number of value models under the income approach umbrella. The two most commonly used are 1) direct capitalisation, and 2) discounted cash flow models.

The direct capitalisation model estimates value by capitalising first year expected net operating income (NOI) by a capitalisation rate extracted from comparable sales. The capitalisation rate is calculated by dividing the first year of expected net operating income by the selling price. For example, if an industrial property sold for $£ 1,000,000$ and had expected first year NOI of $£ 125,000$, it sold at a capitalisation rate of $£ 125,000 / £ 1,000,000=0.08$, or $8 \%$. The inverse of the cap rate is the price/earnings multiplier (or YP), so we can also say our industrial property sold at a multiple of $1 / 0.08=12.5$ times earnings. The valuer selects a cap rate for the subject property based on the rates calculated from comparable sales, and applies it to the subject property's expected first year NOI to arrive at a value estimate. In analysing comparable evidence, it is important to be aware of whether or not the first year net operating income is at Market Rent. If the passing rent is below (or above) the Market Rent, the initial yield will be different from the yield at 'reversion', the point at which the rent payable will revert to the Market Rent, following a rent review or lease renewal. For a fuller explanation see Baum et al. (2015). This phenomenon is most likely to happen where the leasing regime allows for rent to be fixed for long periods between rent revisions back to Market Rent or where there is a disconnect over a long period between the rent revision mechanism and real estate occupier markets (for example, index linking to financial rather than real estate indicators).

The second major category of income approach models is discounted cash flows (DCF). DCF models differ from direct capitalisation in that they explicitly consider all expected cash flows in making the value estimate. The expected cash flows (including terminal value at the end of the forecast holding period), are then discounted to a present value using a discount rate (the required return) that reflects the risk level of the investment. 
As an investor making use of valuation estimates, it is important to understand how the capitalisation rate used in direct capitalisation relates to the discount rate used in DCF models. The link between those rates is understood by keeping in mind that market prices reflect all future expectations. Because the direct cap model explicitly includes only first year income, expectations about future income must be reflected in the capitalisation rate. Based on Gordon's growth model, which has its origins in the equity market, the following relationship is established:

Discount rate $=$ Capitalisation rate + expected annual growth rate of income and value

This discount rate/capitalisation rate relationship works perfectly only when the growth rates of income and value are the same and the rate is the same each year. Though that scenario is virtually impossible, it is a close enough approximation to make the relationship useful for decision making. Note also, the growth estimate reflects inflation and depreciation expectations (assuming the discount rate is also nominal).

For example, if properties are selling at cap rates of 7\%, and the market expects annual growth of $3 \%$, the appropriate discount rate will be $10 \%$. (In reality, this equation is slightly more complex as the annual growth is not necessarily participated in annually, as rents sometimes cannot be raised until a future rent review date or lease expiry. Thus an adjustment has to be made for the rent participation pattern.)

This relationship between cap rates and discount rates has powerful implications for investment decision making, as it provides information about what must occur with respect to income and value over the holding period in order to achieve a target yield. For example, if a property is being considered for the purchase at a cap rate of, say, $5 \%$, and the yield requirement is $12 \%$, that target yield will be achieved only if income and value increase at a rate of $7 \%$ annually.

\section{Strengths and limitations of the income approach}

Because direct capitalisation is effectively a sales comparison model, it benefits from the fact that cap rates are extracted from actual market transactions. Thus, like other units of comparison, cap 
rates reflect the pricing behaviour of the market, which is what the appraiser is attempting to replicate. For this reason, when there are sufficient comparable sales from which to extract a cap rate, most appraisers and investors consider the resulting number to be a relatively reliable estimate of value.

One limitation of direct capitalisation is the need for sales of sufficiently comparable properties. This is typically not an issue for single family properties, but is often an issue for commercial properties. In those cases, the value estimate must come from either the DCF model and /or the cost approach.

The DCF model is more transparent with its inputs than the direct capitalisation approach, in that it requires both explicit forecasts of future cash flows, and an estimate of the discount rate. Its strength is that it explicitly shows those forecasts and the rate, meaning that the investor not only has the 'number' (the single-point price estimate) but also the cash flow and rate assumptions on which the value estimate is based. Where the inputs are derived or implied from market evidence, the resulting valuation, using a DCF approach, should be similar to the value produced by the direct capitalisation approach, albeit with the underlying assumptions exposed to scrutiny. However, where investor specific inputs are used in the DCF model, then the Investment Value or worth to that particular investor is calculated. At this point the investor can compare the market valuation, perhaps calculated using the direct capitalisation approach, with what they should pay for the investment based on their own specific assumptions and requirements.

As discussed above, taken together, cap rates and discount rates provide a powerful tool for analysing the necessary performance to reach a yield objective, that is, given the cap rate at which a property has been purchased, or is being considered for purchase, the difference between that rate and the required yield is a measure of the annual change in income and value necessary to reach that objective.

\section{Summary}


Valuers use three kinds of methodologies to estimate value. They are the sales comparison, cost and income approaches. Conceptually, all three approaches may be used in a given valuation, but in practice data limitations, client requirements, and regulations may favour (or preclude) the use of one or more approach. For Market Value estimates, the sales comparison approach is typically preferred, as it is firmly anchored in the results of market transactions. For Investment Value, discounted cash flow models become relatively more attractive as they are flexible enough to reflect individual investor assumptions and requirements. The cost approach is currently relied on less frequently than the other two approaches for Market Value estimates (except when data limitations or property type mandate its use), but it is a primary tool for development decisionmaking.

\section{Reporting}

In order to avoid any ambiguity and confusion between the valuer and the client, key parts of the valuation process require to be confirmed in writing. Prior to any valuation being undertaken, the client and the valuer should agree in writing the terms of the engagement, including the timescale and the fee. IVS 103 sets out a list of standards that require to be adhered to in the reporting of a valuation to a client. The requirements are:

- Identification and status of the valuer;

- Identification of the client and other intended users;

- Purpose of the valuation;

- Identification of the asset or liability to be valued;

- Basis of value;

- Valuation date;

- Extent of investigation;

- Nature and source of the information relied upon;

- Assumptions and special assumptions;

- Restrictions on use, distribution or publication;

- Conformation that the assignment has been undertaken in accordance with the IVS;

- Valuation approach and reasoning; 
- Amount of the valuation or valuations (stating clearly the currency in which it is expressed); and

- Date of the valuation report.

The requirements are there to ensure that the client knows exactly what has been valued, at what time and on what basis, given a certain set of assumptions. Where a valuer makes additional assumptions, special instructions or departs from the expected norm, then these should be clearly stated. A negative value is possible where the costs of expenditure are greater than the revenue flow, perhaps due to the cost of contamination clean up, and the value should be clearly stated as a negative figure and not as zero.

\section{Summary and conclusions}

It is clear that valuations play a crucial role in real estate investment throughout the differing stages of the investment journey. This chapter has outlined the nature of the valuation profession across the main investment markets, provided an explanation of the varying valuation standards, explained the definitions and bases of valuations as well as illustrating the differing valuation methodologies. However, in a single chapter it is impossible to do full justice to the differences in valuation practice across the globe. Regional differences in practice do exist and users of valuations need to be aware of these differences between the various jurisdictions and how they may affect the valuation.

Across all the countries, the valuation profession is subject to a diverse set of regulatory environments reflecting to some extent their industrial heritage and past and present property market dynamics, which have prompted regulatory action. Nonetheless, all of the countries studied in this chapter share the same ambition to maintain a standard of competency for entry to the profession and continuing proficiency, although the exact levels of education and training required to achieve and maintain full membership differs across jurisdictions and, therefore, the minimum standard is not uniform. While government regulation may also exist, self-regulation of professional conduct and standards by the in-country professional associations is common in most of the jurisdictions. 
With respect to valuation standards, the last 30 years have witnessed the growth of The International Asset Valuation Standards Committee (TIAVSC), which enjoys a wide membership and influence across 57 countries. The resulting International Valuation Standards (IVSC) now sit alongside country-specific standards, introduced to reflect unique domestic market characteristics, such as those involving property rights, title, lease structures and perceived best practice. In many countries, notably in the UK and US, the updating of the valuation standards has often been precipitated by some form of property market crisis. While this dual level of standards does lead to the risk of potential contradiction, due to the wide acceptance of the international standards much consistency exists on the key definitions of value and the bases of valuation. The recent introduction of International Property Measurement Standards for Offices is a good illustration of the collaborative work of TIAVSC to ensure the consistent measurement of a property asset, which attracts considerable amounts of global capital and which, prior to this new standard, had been subject to a variety of different measurement approaches, thus making consistent analysis of yields and total returns across markets difficult to undertake.

While there is broad consistency on definitions and bases of valuations, the valuation methodologies adopted tend to reflect local custom and practice albeit within the guidance provided by the in-country professional associations. That said, the principles underpinning the sales, income and cost approach to valuation are accepted across all markets, albeit the terminology used may differ and their application may be subject to the level of transparency in the local market and the volume of transaction evidence. Market transparency is different between London and Beijing and between Madrid and Mumbai and, thus, the techniques used to estimate value have to adapt to the availability of market evidence. In opaque and thin markets, uncertainty exists as to the correct level of value and this additional risk needs to be communicated properly to the client. The users of valuations tend to demand single point estimates of value which may not be backed up by fully verifiable recent transaction evidence and this needs to be flagged.

Whether or not there are differences in market practice within different regions and between countries, it is essential that there is absolute clarity between the valuer and the client on the purpose and basis of value and the legal and market context within which the value of the property 
is estimated. Valuations are required at point of purchase and sale and throughout the holding period to assess performance and it is thus essential that users of the valuation understand the context and the approach adopted. 


\section{Appendix A: Market background}

Australia

Land Legal definition of land includes the ground and any building improvements on and everything attached to the land.

Property

Rights

Title $^{6} \quad$ Crown Land: All land in Australia is Crown land unless alienated by grant, sale All land is held under tenure from the Crown. The highest form of ownership is an estate in fee simple.

Lesser forms of ownership include leasehold, joint tenancy, and tenancy in common.

or resumption. The Crown manages Australia's land in a variety of ways such as free grant, freehold alienation, short term leases and licenses.

Old System title: Prior to the establishment of the Torrens system, land ownership was based on the English common law system known as 'Old System'. Unlike Torrens title, Old System title is good title only if a better claim cannot be established. A chain of evidence (known as a chain of title or chain of deeds) is needed to establish good title.

Torrens title: This is a system that establishes title based on registration and certification, and not on deeds. Title held under the Torrens system is guaranteed by the Australian government.

Native title: Australia has taken steps to recognise the native title of indigenous Aboriginal and Torres Straits Islander peoples who made up 3\% of the Australian population as at $2011^{7}$. Native title is a property right which reflects a relationship to land which is the very foundation of indigenous religion, culture and well-being. ${ }^{8}$

Units of Metric system (SI): square metres, or cubic metres where cubic capacity is Measurement relevant say in industrial buildings. For residential property transactions, land prices may be referenced using traditional British imperial measures (price per acre or per perch).

\section{Office}


Typical Lease Three to five-year leases, with annual or mid-term reviews for market or Structure inflation pegged adjustments are the norm for office space leases. Larger tenants may be granted 7-10 year leases. ${ }^{9}$

Rents are paid monthly in advance. Tenants bear all outgoings relating to the building based on their leased floor space and a share of outgoings of common areas based on the proportion of their leased floor space to the total leased area of the building. Such outgoings include repairs, maintenance, cleaning, utility costs, property management, building insurance, land tax etc.

\section{Retail}

Speciality retail leases are generally for three to five years, with option to renew and rent reviews similar to that for an office space lease. Anchor tenants are given much longer leases, from 10 to 40 years on favourable terms to the tenant. Renewals are typically made on the same terms as the original lease save for rents which will be revised. Percentage or turnover rents are sometimes paid. Outgoings paid by the tenant are similar to that of office tenants, but there may be additional expenses such as promotional levies or merchants' association fees.

\section{Industrial}

Lease of industrial space varies with the size of the property and range from three, five, or 10 years, with market or inflation adjusted rent reviews. Smaller units of industrial space are often held under a strata-title ${ }^{10}$ and may be leased on a gross or net basis.

The tenant is responsible for all outgoings including management, but excluding structural repairs which involve capital expenditure.

CHINA

Property Pursuant to the PRC Constitution adopted in 1982, there is no private Rights ownership of land in China; land in urban areas is state-owned, whereas land in rural and suburban areas is generally owned by collective economic organisations for the benefit of the people. ${ }^{11}$ 
Economic dealings with collectively-owned land are highly restricted and typically cannot be used for non-agricultural purposes, unless approved by the government.

Individuals and businesses may acquire 'use rights' in state-owned land by way of allocation or grant. Use rights give the holder the right to occupy, build and operate on the land. PRC law generally provides for 'granted' land use rights and 'allocated' land use rights.

\begin{tabular}{|c|c|}
\hline Granted land use rights & Allocated land use rights \\
\hline Granted by the state & Allocated by local government \\
\hline Right to transfer, lease or mortgage & $\begin{array}{l}\text { Right to transfer, lease or mortgage } \\
\text { subject to government approval }\end{array}$ \\
\hline $\begin{array}{l}\text { Fixed term: } \\
\text { Residential purpose - up to } 70 \text { years } \\
\text { Industrial purpose - up to } 50 \text { years } \\
\text { Commercial purpose - up to } 40 \text { years }\end{array}$ & $\begin{array}{l}\text { No definite period of allocation, } \\
\text { dependent on specific use and } \\
\text { regulatory requirements. }\end{array}$ \\
\hline $\begin{array}{l}\text { Payment of land grant premium and } \\
\text { annual land use fee. }\end{array}$ & $\begin{array}{l}\text { No land premium payable. If land is } \\
\text { occupied, user must bear } \\
\text { resettlement costs. }\end{array}$ \\
\hline $\begin{array}{l}\text { Granted by way of mutual } \\
\text { agreement, invitation of tender or } \\
\text { auction. In practice it is often carried } \\
\text { out by negotiated agreement. }\end{array}$ & $\begin{array}{l}\text { Involves negotiated agreement with } \\
\text { local government and occupants of } \\
\text { land, if any. }\end{array}$ \\
\hline $\begin{array}{l}\text { There is a registration and certificatior } \\
\text { users and owners to apply for land } \\
\text { certificates. }{ }^{12}\end{array}$ & n system in place which requires 1 \\
\hline
\end{tabular}

Units of Square metres is the typical unit of measurement. For land, the traditional Measurement Chinese unit of measure, the $m u(1 \mathrm{mu}=666.667$ square metres $)$ may be used. 
Typical Lease Leases can be granted by the holder of the land use rights and are typically for Structure a term of two years, with an option to renew for a further two to three years at prevailing market rental rates. Rent is payable monthly, and is usually reviewed as part of the renewal negotiations.

As noted in the JLL Global Real Estate Transparency Index 2016, China's real estate practice is semi-transparent and there is room for greater transparency to enable investors to make more informed real estate decisions. However, in Tier 1 Cities, the situation is improving and China is coming closer to breaking into the transparent block of countries.

\section{HONG KONG}

Land Under the Conveyancing and Property Ordinance, Chapter 219, 'land' includes (a) land covered by water; (b) any estate, right, interest or easement in or over any land; (bb) the whole or part of an undivided share in land and any estate, right, interest or easement in or over the whole or part of an undivided share in land; and (c) things attached to land or permanently fastened to anything attached to land.

Property Today, all the land in Hong Kong is owned by the People's Republic of China Rights (the Hong Kong SAR government), save for the land on which St John's Cathedral stands. ${ }^{13}$ Land leases are sold by the government by public auction, tender or private treaty grant. Before July 1997, the term of leases granted by the Crown varied from 999 years, to 99 years, to 75 years. However, government leases granted after July 1997 are 50-year leases except those for special purposes. ${ }^{14}$ Further, in addition to a land premium, the acquirer is also required to pay land rent being an amount equivalent to $3 \%$ of the rateable value assessed by the Rating and Valuation Department. ${ }^{15}$

Title Hong Kong is in the process of transitioning from a deeds registration system to a title registration system. The deeds registration system provided a record 
of registration for all instruments which affect land or interests in land in Hong Kong, but involved a cumbersome and uncertain search process. The title system will make public searches more accessible and transparent, and reduce the burden on potential purchasers in ascertaining the identity of legal and equitable owners.

Units of Square metres is the typical unit of measurement.

\section{Measurement}

Typical Lease Residential space is generally leased for two-year terms with a break clause Structure after the first year whereby the lease is terminable with two to three months' notice.

Office and retail leases are typically three-year fixed term leases. Rent is payable monthly; rental rates are subject to negotiations during renewal discussions. The landlord is responsible for internal repairs and repairs of the common areas, but these costs are sometimes passed on to the tenants in the form of a service charge.

\section{INDIA}

Land 'Land' includes benefits to arise out of land, and things, attached to the earth or permanently fastened to anything attached to the earth. ${ }^{16}$

Property Most properties in India are freehold properties. Apartments are typically sold Rights on a leasehold basis of 30, 60 or 99 years.

Title India adopts a 'recording system' similar to that in the United States. This system involves registration of deeds in a system of 'presumptive' title. Land records are not conclusive evidence of title, but simply records of transactions and registration. ${ }^{17}$ Owners typically purchase title insurance to insure against loss or damage sustained in connection with errors in title examination, defects, liens or encumbrances on the title. ${ }^{18}$

Units of There are numerous units of measurements used in India. In Delhi, Gurgaon Measurement and Noida, property and land measurements are made in square feet; in Mumbai and Goa, measurement is done in square metres. In other states like 
Uttarakhand and Himachal Pradesh, the Nalli (1 Nalli $=240$ square yards) is used.

Typical Lease A typical commercial lease has a term of three years with an option to renew Structure for a further two years. Rent is payable monthly in advance with rent reviews negotiated up front, with fixed increments of between 15-20\% every three years or $5 \%$ annually.

Tenants are responsible for internal fitting out, whilst landlords are responsible for structural and external repairs, repairs of common areas and insurance for the building.

Subletting is usually prohibited save with the landlord's approval.

JAPAN

Land Land and buildings are regarded as separate and independent real estate, and can have different owners.

Property The two main categories of land ownership rights in Japan are similar to the Rights concepts of freehold and leasehold. Shoyuken (freehold) is absolute ownership of land and building. Chishakuken is a leasehold interest that gives the holder a right to occupy and use the property.

Other lesser property rights include Chijoken, a right to use the land of others to own structures on that land; Chiekiken, a right to use the land of others for certain specific purposes non-exclusively; and Tanpoken, a right to create a security. ${ }^{19}$

Title There is no title system in Japan, but there is a system for registration of land and buildings (fudosan tokibo). Ownership is perfected via a time-consuming boundary confirmation process which involves the procurement of signatures of all adjoining property owners to evidence agreement of the site boundary.

Units of A combination of metric and traditional units of measure (tsubo or jo) is used Measurement in Japan. A tsubo is equal to 35.58 square feet (the area of two standard sized tatami mats); a jo is equal to half of a tsubo. Real estate areas may be quoted in tsubo or square metres, but rents and prices per unit are based on tsubo. 


\section{Typical Lease Office}

Structure A standard lease of office space in Japan usually has a two-year term, a statutory renewal right and a break clause exercisable by the tenant with six months' notice. Fixed-term leases are common in larger and newer office buildings. Rents are payable monthly. Landlords may require three types of deposits: Shiki kin (six to 12 months' rent) for unpaid rent and reinstatement; Kenri kin (two to six months' rent) for key money, which is non-refundable; and Hosho kin, a refundable deposit paid before lease commencement which is commonly used to help fund the construction of the building.

\section{Retail}

Retail leases are similar in structure to office leases but may contain a percentage rent provision. Anchor tenants are granted longer terms with a rent review mechanism in the lease. Smaller tenants may have very short leases, even month-to-month.

\section{Residential}

A lease for an apartment is usually for a term of two years. The tenant has to bear utility costs and the tenant's employer is usually required to co-sign the lease.

\section{SINGAPORE}

Land The legal definition of land includes the ground and any building improvements on and everything attached to the land.

Property The highest form of ownership is an estate in fee simple. Other forms of Rights ownership include an estate in perpetuity by way of a state land $\operatorname{grant}^{20}$, leasehold, joint tenancy, and tenancy in common. Freehold or leasehold estates may be subject to legal restrictions e.g. rights of way and easements.

Title Land registered under the Land Titles Act (LTA) (Torrens system) has indefeasible title. 
Land not registered under the LTA are regulated by the English common law system of deeds. Although there is a separate system of registration for deeds, registration of a deed does not guarantee good title.

Units of Square feet or square metres.

\section{Measurement}

Typical Lease A lease of office or retail space in Singapore is typically for a term of one to Structure three years. Owing to a highly competitive local retail space market, the retail landlord would typically require annual fixed upwards rent revisions and a redevelopment or 'break' clause. Turnover or percentage rent may be payable by a retail tenant in addition to a base monthly rent.

The tenant is responsible for all outgoings relating to the property and would usually pay a service charge; and in the case of a tenant occupying premises owned by a retail real estate investment trust, an additional advertising and promotional fee is payable.

Industrial leases acquired from the JTC Corporation, the main statutory board overseeing industrial land in Singapore, tend to be for longer terms. A recent change in policy has stipulated that the maximum tenure of industrial leases from JTC will be reduced from 60 years to 30 years.

\section{UK}

Land The legal definition of land includes the ground and any building improvements on and everything attached to the land

Property The two principal rights in land are freehold and leasehold. Freeholders hold Rights an estate from the Crown in perpetuity (fee simple) while leaseholders are granted the use of the land and buildings for a certain term of years.

Title The Land Registry holds records about most property or land sold in England or Wales since 1993 while the Land Register in Scotland was introduced in 1981.

Units of Square feet or square metres.

\section{Measurement}


Typical Lease Commercial and industrial property occupational leases in the UK have Structure become much more diverse since the end of the 1980s when over $90 \%$ of the leases held by the major institutional investors and property companies were for 20-25 years, had five yearly upwards only rent reviews and full repairing and insuring (FRI) liabilities by the tenant. There is now a diversity of lease lengths, often 5, 10 or 15 years, tenant breaks are common but the 5-year upwards-only rent review to Market Rent has survived, supporting the use of incentives such as rent free periods and capital payments upon new lettings. Indexation and other rent revision types are sparsely utilised at present. The higher value properties let to corporate tenants attract the longest leases. Rents are normally paid in advance, quarterly or half yearly.

US

Real Estate Real estate and real property are terms often used interchangeably, but they and Real have slightly different meanings. Real estate is land plus improvements on and Property to the land, whether natural or man-made. Real property is broader in meaning. It is real estate plus all legal rights, powers, and privileges inherent in the ownership of property.

Property Ownership of real property is by freehold estate. The highest form of freehold Rights estate is an estate in fee simple absolute. Lesser forms of ownership include fee simple defeasible and life estates. Non ownership estates are called nonfreehold (or leasehold) estates. They are of limited duration, and are created by a lease or rental agreement. Both freehold and non-freehold estates may be subject to legal or contractual restrictions such as easements or rights-of-way.

Title Transfer of title is described in law as alienation. Alienation may be voluntary or involuntary. Voluntary title transfer is accomplished by the delivery of a valid deed by the grantor to the grantee. Involuntary title transfer may occur as a result of a lien foreclosure sale, adverse possession, filing a petition in bankruptcy, or condemnation under the power of eminent domain.

Units of The most common unit of measurement is the square foot, whether referring to Measurement land or buildings. Land size is sometimes quoted in acres, and the 
measurement of certain kinds of buildings, for example industrial buildings, may include height as well as floor space.

Typical Lease Market conditions largely drive commercial lease structures and terms, so there Structure is not an industry standard. However, during 'normal' market conditions, three to five year leases are common for office space, with industrial and retail leases often five or more years. Rent may be fixed, but more often escalates periodically by an agreed upon percentage, or as a function of an inflation index or reappraisal. Commercial leases also vary widely with respect to the responsibility for operating expenses. Longer term industrial properties are often leased on a 'triple net' basis, meaning the tenant is responsible for all operating expenses. Quoted nominal rental rates must be carefully analyzed, as they may differ significantly from the effective rate including expenses. 


\section{References}

Appraisal Institute (2014) Valuation institute history, http://www.valuationinstitute.org/about/our-history

Australian Property Institute. (2012) Australia and New Zealand valuation and property standards, January 2012 Edition, Australian Property Institute: Deakin.

Australian Valuation Office (AVO) (2010) 100 years of the Australian Valuation Office, Australian Valuation Office: Canberra.

Baum, A., Mackmin, D. and Nunnington, N. (2015) The income approach to property valuation, Routledge: London.

Crosby, N., French, N. and Oughton, M. (2000) Bank lending valuations on commercial property: does the European mortgage lending value add anything to the process?, Journal of Property Investment and Finance, 18(1), 66-83.

Crosby, N., and Hughes, C. (2011) The basis of valuations for secured commercial property lending in the UK, Journal of European Real Estate Research, 4(3), 225-242.

Davies, T.D. (1908) Curtis on the valuation of land and houses (3 ${ }^{\text {rd }}$ Edition), Estates Gazette: London.

Diaz, J. (2002) Behavioural research in valuation and some perspectives on implications for practice, RICS Research Review Series, RICS: London.

Edelstein, R.H. and Quan, D.C. (2006) How does appraisal smoothing bias real estate returns measurement?, Journal of Real Estate Finance and Economics, 32(1), 41-60.

EVS (2016) European Valuation Standards $8^{\text {th }}$ Edition), TEGOVA: Bruxelles.

Gelbtuch, H. C. (Ed.) (2011) Real estate valuation in global markets, $2^{\text {nd }}$ Edition, Appraisal Institute: Chicago.

Geltner, D., MacGregor, B.D. and Schwann, G. M. (2003) Appraisal smoothing and price discovery in real estate markets, Urban Studies, 40(5-6), 1047-1064.

Hong Kong Conveyancing and Property Ordinance (1997) Chapter 219.

Indian Banks' Association, National Housing Bank and School of Planning and Architecture, New Delhi. (2009) Handbook on policy, standards and procedures for real estate valuation by banks and HFIs in India, Final Report November 2009.

IVSC (2011) Code of ethical principles for professional valuers. International Valuation Standards Council: London. 
IVSC (2012) A competency framework for professional valuers, International Valuation Standards Council: London.

IVSC (2017) International Valuation Standards 2017, International Valuation Standards Council: London.

IVSC (2014) Valuation uncertainty, Technical Information Paper No 4, International Valuation Standards Council: London.

IVSC (2017) International Valuation Standards Committee Annual Report 2015-16, https://www.ivsc.org/about/annual-reports

Jomo, K.S. and Wong, S.N (Eds.) (2008) Law, institutions and Malaysia economic development, NUS Press.

Jones Day (2004) International Real Estate Briefing, Real Estate Practice in China, September 2004.

Jones Lang Lasalle (2016) Global Real Estate Transparency Index 2016, JLL. http://www.jll.com/GRETI.

Jones Lang LaSalle (2013) Japan Property Investment Guide 2013, JLL.

Jones Lang LaSalle, Kim \& Lee and Blake Dawson (2011) South Korea Property Investment Guide 2011, JLL.

Lawrence, D.M. and May, H.G. (1943) Modern methods of valuation, Estates Gazette: London.

Li, L-H, (2006) Development valuation of land in Hong Kong, Revised Edition, The Chinese University Press.

Property Institute (2014) New Zealand Property Institute - who are we. http://www.property.org.nz/Category?Action=View\&Category_id=699

Practical Law Company (2010) Corporate real estate handbook 2010/11.

Gupta, P.S. (2010) Ending finders, keepers: the use of title insurance to alleviate uncertainty in land holdings in India, U.C. Davis Journal of International Law and Policy, 17, 63-109.

RICS (2014) RICS History. http://www.rics.org/uk/about-rics/who-we-are/history/

RICS (2017) RICS Valuation - Global Standards 2017. RICS: London.

Ruchardt, K. (2003) Mortgage lending value, Fritz Knapp Verlag: Frankfurt am Main.

TEGOVA (2014) TEGoVA guidance to EU member states and candidate member states on development of reliable valuation standards in accordance with Art. 19 of Directive 2014/17/EU 
on credit agreements for consumers relating to residential immovable property (also known as the Mortgage Credit Directive, TEGOVA: Bruxelles.

USPAP. (2014) Uniform standards of professional valuation practice, Appraisal Foundation: Annapolis Junction, US. 


\section{Notes}

${ }^{1}$ The Hong Kong Institute of Surveyors, http://www.hkis.org.hk/en/hkis aboutus.php. [Accessed on 29 October 2014.]

${ }^{2}$ The Institution of Surveyors, http://iosindia.org/valuation.html. [Accessed on 29 October 2014.]

${ }^{3} \mathrm{http} / / / \mathrm{www}$.sisv.org.sg/overview. [Accessed on 31 October 2014.]

${ }^{4}$ In an analysis of retail cap rates within Europe by IPD in 2004, the UK retained $97 \%$ of gross to net income while Germany and the Scandinavian countries only retained around $80 \%$

${ }^{5} \mathrm{~A}$ covered bond is a security created from public sector loans or mortgage loans where the security is backed by a separate group of loans; it typically carries a maturity rate of two to 10 years and enjoys relatively high credit ratings. Covered bonds provide an efficient, lower-cost way for lenders to expand their business rather than issuing unsecured debt instruments.

${ }^{6}$ Old System Information and Search Guide, March 2013, Land and Property Information, NSW Government.

${ }^{7}$ Estimates and Projections, Aboriginal and Torres Strait Islander Australians, 2001 to 2026, Australian Bureau of Statistics,

http://www.abs.gov.au/ausstats/abs@.nsf/Products/C19A0C6E4794A3FACA257CC900143A3D?opendocument. Accessed on 28 October 2014.

${ }^{8}$ Australian Human Rights Commission, https://www.humanrights.gov.au/native-title. [Accessed on 28 October 2014.]

${ }^{9}$ Australian Real Estate investment Guide 2013, Savills.

${ }^{10}$ Strata-title allows individual ownership of part of a property (such as a townhouse), combined with shared ownership in the remainder - the 'Common Property' (e.g. foyers, driveways, gardens).

${ }^{11}$ International Real Estate Briefing, Real Estate Practice In China, Jones Day, September 2004.

${ }^{12}$ Ibid.

13

http://www.hkclic.org/en/topics/saleAndPurchaseOfProperty/basic_knowledge_of_land_ownership_in_hong_kong/. [Accessed on 29 October 2014.]

${ }^{14}$ Development Appraisal of Land in Hong Kong, Ling-hin Li, at pp. 19-20.

${ }^{15}$ Ibid., at pg 38 .

${ }^{16}$ Dictionary of Valuers, Practising Valuers Association India, http://www.pvai.info/dictionary of valuers.php. [Accessed on 29 October 2014.]

${ }^{17}$ At page 68 .

${ }^{18}$ At pp. 70-71.

${ }^{19}$ Japan Property Investment Guide 2013, Jones Lang LaSalle.

${ }^{20}$ The payment of nominal ground of SGD \$12 per year has been waived since 1992. 